\title{
Late Quaternary marine-based Kara Sea ice sheets: a review of terrestrial stratigraphic data highlighting their formation
}

\author{
Ólafur Ingólfsson ${ }^{1}$, Per Möller² \& Hanna Lokrantz ${ }^{3}$ \\ 1 Department of Earth Sciences, University of Iceland, Askja 233, IS-101 Reykjavik, Iceland \\ 2 GeoBiosphere Science Centre, Quaternary Sciences, Lund University, Sölvegatan 12, SE-22362 Lund, Sweden \\ 3 Geological Survey of Sweden, Villavägen 18, Box 670, SE-75128 Uppsala, Sweden
}

\section{Keywords}

Kara Sea; Late Quaternary; marine-based ice sheet; western Siberia.

\section{Correspondence}

Ólafur Ingólfsson, Department of Earth

Sciences, University of Iceland, Askja 233,

IS-101 Reykjavik, Iceland. Email: oi@hi.is

doi:10.1111/j.1751-8369.2008.00060.x

\begin{abstract}
Reconstructions of the Late Quaternary glacial history of the Kara Sea area show repeated build-up of ice-sheet domes over the shallow epicontinental Kara Sea. Inferred ice divides were situated over the central Kara Sea, and the ice sheet repeatedly inundated the surrounding coastal areas of western Siberia. Geological fingerprinting of the Kara Sea ice sheet include end moraine zones, raised beaches, tills, glaciotectonic deformations and coarsening-upward sediment sequences, reflecting isostatic rebound cycles. This paper reviews evidence from several areas along the perimeter of the Kara Sea, suggesting that peripheral sites were critical for the initiation of the large Kara Sea ice sheet. Ice-sheet inception progressed with the formation of local ice caps that later coalesced on the adjacent shelf with globally falling sea levels, eventually merging and growing into a large ice dome.
\end{abstract}

The epicontinental Kara Sea, and coastal areas and islands of western Siberia, were repeatedly glaciated by Kara Sea ice sheets during the Late Quaternary (Forman et al. 2002; Svendsen et al. 2004; Möller et al. 2007). Although contradicting hypotheses have been proposed for icesheet geometries, including the location of ice divides, limits and ages for various ice-sheet configurations (Velichko et al. 1997; Grosswald \& Hughes 2002; Svendsen et al. 2004), there is a growing consensus around the syntheses of spatial and temporal variations of past Eurasian High Arctic ice sheets, stemming from work carried out under the Quaternary Environment of the Eurasian North (QUEEN) programme (Svendsen et al. 2004; Fig. 1). Svendsen et al. (2004) evaluated and summarized data collected by a number of groups over the past 10-15 years, which resulted in a model where successively smaller ice volumes are recognized in the Kara Sea basin since marine oxygen isotope stage 6 (MIS 6) (Fig. 1). Although the reconstructions of Larsen et al. (2006) and Lambeck et al. (2006) differ in many respects from that of Svendsen et al. (2004) on regional Barents Sea-Kara Sea ice extent and timing of glacial and marine events, these studies do not contradict the conclusion of Svendsen et al. (2004) that earlier Kara Sea glaciations were more extensive than later glaciations, and that the Kara Sea shelf did not hold a major ice sheet during the Last Glacial
Maximum (LGM). Glaciological modelling has resulted in reconstructions that simulate Barents Sea-Kara Sea icesheet extent and volume on different time slices in fairly good agreement with these field observations and chronological constraints (Siegert et al. 2001; Forman et al. 2004; Lambeck et al. 2006).

An inherent problem when it comes to reconstructing glacial oscillations over a full glacial-interglacial cycle is that the geological evidence foremost reflects maximum ice-sheet extent and volume, and subsequent deglaciation and sea level changes (ice marginal features, tills, glacial lineations [flutes and drumlins], glaciotectonic deformations, ice-rafted debris [IRD] records, raised beach sequences). However, there is not much evidence for the mechanics and dynamics of the build-up phase that led to a maximum ice extent during a stadial in the glacial cycle. One particular challenge is to understand and explain how to build marine-based ice sheets like the former Barents Sea and Kara Sea ice sheets. The purpose of this paper is to review and summarize novel data collected under the QUEEN programme field campaigns, but also includes post-QUEEN research on the Taymyr Peninsula and in Severnaya Zemlya, with an emphasis on data that highlight the possible dynamics of marine-based ice-sheet formation. These data come from four sites around the Kara Sea: the Yamal Peninsula (Forman et al. 2002; 
Fig. 1 Reconstruction of ice extent in the Barents-Kara Sea region, for selected time slices, since $140 \mathrm{Kya}$; modified from Svendsen et al. (2004). A more sophisticated and somewhat different reconstruction by Lambeck et al. (2006), particularly regarding the Early-Middle Weichselian ice extent, may prove more correct when tested against new field data.

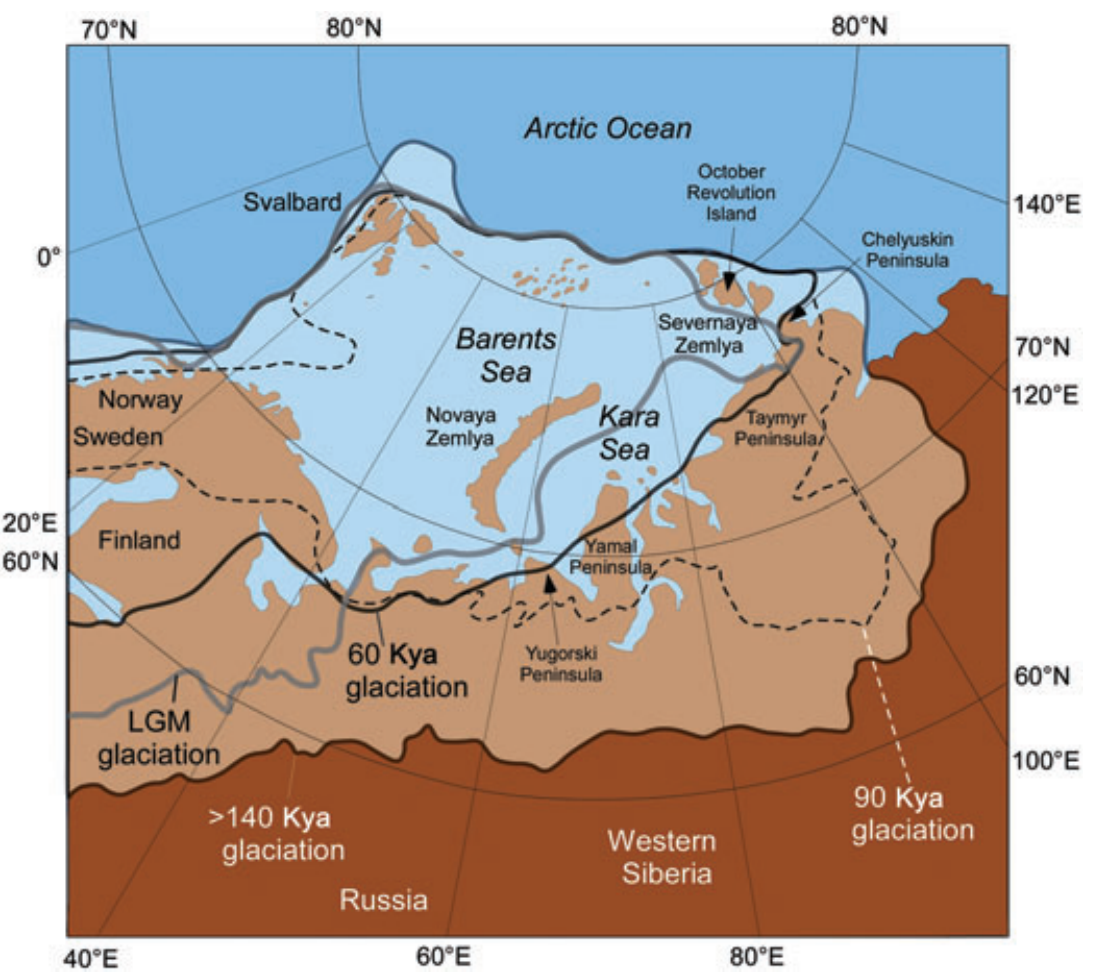

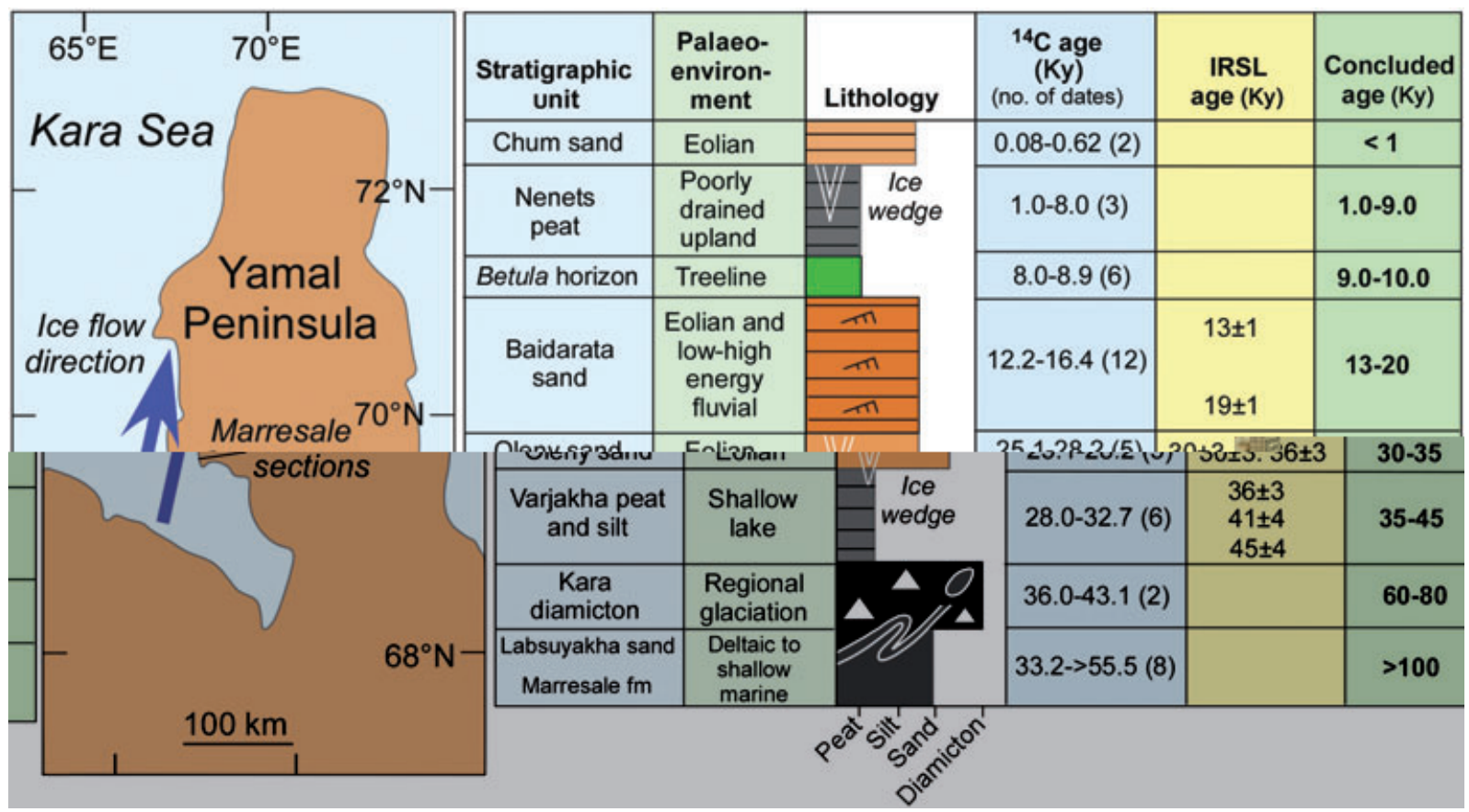

Fig. 2 Stratigraphy of the Marresale coastal cliffs, Yamal Peninsula. The blue arrow indicates ice movements from southerly directions across the site $>60 \mathrm{Kya}$, as reconstructed from structural and textural data. Stratigraphy modified from Forman et al. (1999) and Forman et al. (2002). 
Forman et al. 2004), the Yugorski Peninsula (Lokrantz et al. 2003), October Revolution Island in Severnaya Zemlya (Möller et al. 2006) and the Chelyuskin Peninsula (Möller et al. 2008 [this issue]). In addition, data from the north-western Taimyr Peninsula (Hjort et al. 2003; Hjort \& Funder 2008 [this issue]) are briefly discussed.

\section{Field evidence}

\section{The Yamal Peninsula evidence}

The stratigraphy and architecture of the Marresale sections, western Yamal Peninsula (Fig. 2), were described and discussed by Gataullin (1988), Astakhov et al. (1996), Forman et al. (1999) and Forman et al. (2002). The stratigraphy of the Marresale coastal cliffs shows that the south-eastern sector of the Kara Sea area was not glaciated during the LGM. The Kara diamicton in the Marresale sections relates to Kara Sea glaciation prior to 50 Kya. It is a complex unit containing large ice bodies, and massive and stratified diamictons. The basal contact of the Kara diamicton is erosive and tectonically discordant, with ice pressure from the south resulting in numerous large $(>10 \mathrm{~m})$, nearly isoclinal, recumbent to gently inclined folds (Fig. 3). Large, overturned chevron folds are very conspicuous, with uniform vergence toward the north. Other deformation structures range from tight, low-angle thrust faults and recumbent folds to small-scale boudinage structures and shear bands. Locally, the underlying Labsuyakha sand has been drawn into the diamicton and sheared out along thrust faults. Large chunks of the sand have also been dislocated and rotated, with primary sedimentary structures preserved in intraclasts with sharp contacts to the surrounding Kara diamicton (Fig. 3). All glacial tectonic structures indicate overriding ice-flow from the SSW.

Forman et al. (2002) tentatively dated the deposition of the Kara diamicton and the accompanying glaciotectonic displacements to $60-80 \mathrm{Kya}$, and it is correlated with the Middle Weichselian (ca. 60 Kya) glaciation in the Svendsen et al. (2004) synthesis. This age interpretation is supported by the observation that the Varjakha peat and silt, overlying the Kara diamicton, and dated with ${ }^{14} \mathrm{C}$ and optically stimulated luminescence (OSL) to 28-45 Kya, was partly formed in kettle holes in the diamicton surface. The ice-movement direction is, however, problematic in the perspective of an ice divide situated over the Kara Sea, as implied by the Svendsen et al. (2004) reconstruction.

\section{The Yugorski Peninsula evidence}

A study by Lokrantz et al. (2003) focused on the Late Quaternary glacial stratigraphy and glaciotectonic struc-
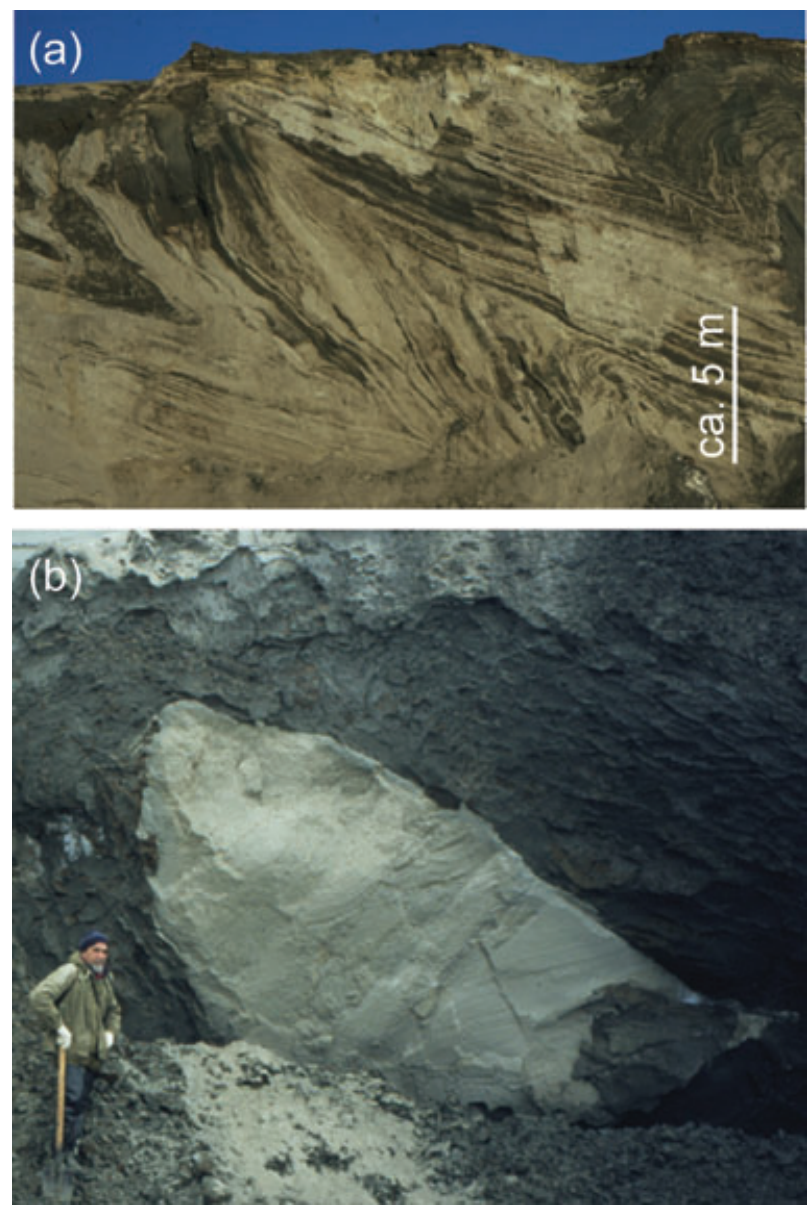

Fig. 3 Glaciotectonic structures in the Marresale coastal cliffs. (a) Large chevron folds. The vergence is towards the north. (b) Large clast of sand incorporated to the Kara diamicton from underlying sediments. (Photos by Ó. Ingólfsson, 1996.)

tures of the Cape Shpindler coastal cliffs on the Yugorski Peninsula (Fig. 1). The Cape Shpindler site is situated at the south coast of the Kara Sea, across the Baidarata Bay from Marresale sections on the Yamal Peninsula (Fig. 4). Lokrantz et al. (2003) recorded two glacier advances and two ice-free periods older than the Holocene. Their oldest stratigraphical units (A-C2, Fig. 4) form a sequence of marine to fluvial sediments. The marine facies contain foraminifera and subfossil mollusc fauna that together suggest deposition under interglacial conditions. Subsequent to this interglacial followed a glacial event when ice moved southwards from an ice divide over Novaya Zemlya or the Kara Sea, overriding and disturbing the interglacial sediments. At deglaciation this glacial advance left a complex of till and buried massive glacier ice (unit D, Fig. 4). The interpretation of age controls suggests that glacial event D could possibly be MIS 8 (300-250 Kya; Lowe \& Walker 1998), and that the 




\begin{tabular}{|c|c|c|c|c|}
\hline Unit & Lithology & Palaeoenvironment & ${ }^{14} \mathrm{C}$ age (Ky) & IRSL age (Ky) \\
\hline G & $\bar{E}$ & $\begin{array}{l}\text { Tundra environments; } \\
\text { lacustrine, eolian, fluvial }\end{array}$ & $\begin{array}{c}12.5-4.4 \\
\text { (18 dates) }\end{array}$ & \\
\hline $\mathrm{F}$ & $\Delta \Delta \Delta$ & Glacial advance from S & & \\
\hline $\mathrm{E}$ & $\frac{N}{\pi}$ & Delta & $\begin{array}{c}>40 \\
\text { (4 dates) }\end{array}$ & $\begin{array}{c}>120 ;>140 \pm 12 \\
175.8 \pm 18.6\end{array}$ \\
\hline D & $\underset{\mathrm{Ice}}{\boldsymbol{\Delta}}$ & Glacial advance from $\mathrm{N}$ & $\begin{array}{c}44 ; 44.5 ; \\
\text { (infinite ages) }\end{array}$ & \\
\hline ic2 & $\frac{\pi}{\pi}$ & Delta plain & $\begin{array}{l}46.4 ; 49.9 \\
\text { (infinite ages) } \\
40.3\end{array}$ & \\
\hline B &  & Pro-deltaic & & \\
\hline A & & Shallow marine & & \\
\hline
\end{tabular}

Fig. 4 Stratigraphy of the Cape Shpindler site, Yugorski Peninsula (modified from Lokrantz et al. 2003). The blue arrows indicate ice movements from southerly directions across the Cape Shpindler and Marresale sites $>60 \mathrm{Kya}$, as reconstructed from structural and textural data.

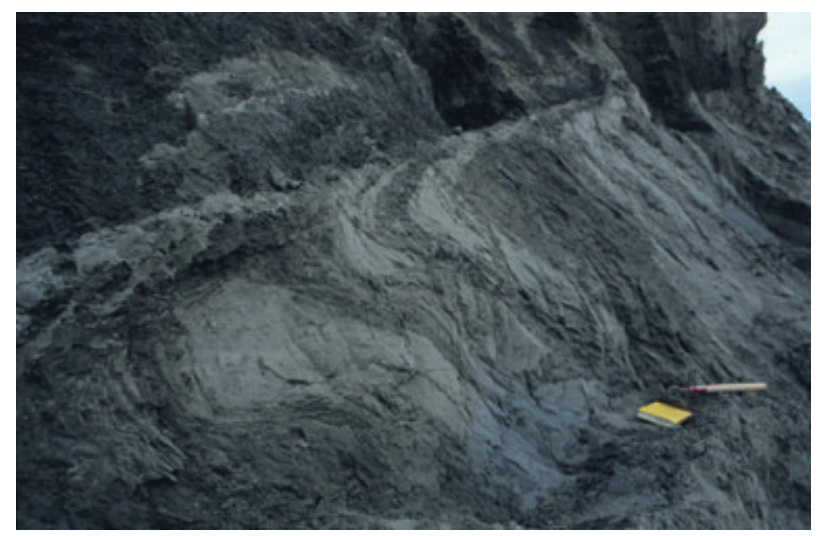

Fig. 5 Glaciotectonic structures in the Cape Shpindler coastal cliffs: dragfold below a thrust fault and till of unit F. (Photo by H. Lokrantz, 1999.)

underlying interglacial sediments (units A-C2) thus might be Holsteinian in age (MIS 9; >300 Kya). Following this glaciation there was a second period of fluvial deposition, during which unit E was deposited under interstadial or interglacial conditions (Fig. 4). Unit E is interpreted to represent delta sediments, deposited in a lake setting rather than a marine environment. The dating control suggests this unit to be older than 120 Kya.

Sometime later, the Cape Schpindler area was again subject to glacial overriding, with the ice now moving northward, towards the Kara Sea, from an inland ice divide. The evidence for this glacial overriding is a compact till (unit F, Fig. 4), as well as glaciotectonic deformation of the underlying unit E sand and mud (Fig. 5). The age of this youngest glacial event recognized in the Cape Shpin- dler sections is poorly constrained, but Lokrantz et al. (2003) interpreted its stratigraphical position as indicating it to be of an Early to Middle Weichselian age (MIS 5d-4). They correlated it to the glacial event that caused the deposition of the Kara diamicton on Yamal Peninsula. As with the Marresale record, the Cape Shpindler record suggests more complex glacial dynamics than can be explained by a concentric ice sheet located on the Kara Sea shelf. Lokrantz et al. (2003) suggested that ice had moved across the Cape Shpindler site from an ice divide situated across the Pai Hoi uplands, which for the most part have an altitude of about $200 \mathrm{~m}$ a.s.l., but reach almost $500 \mathrm{~m}$ a.s.l. at the highest elevation (Fig. 4).

\section{The October Revolution Island evidence}

Recently, the glacial history of Severnaya Zemlya has been addressed by Raab et al. (2003) and Möller et al. (2006, 2007). Whereas Raab et al. (2003) studied environmental proxies in a lake core from Changeable Lake on October Revolution Island (Fig. 6), Möller et al. (2006, 2007) focused on glacial history evidence in the lithostratigraphical record of a number of sections along the Ozernaya River on October Revolution Island (Fig. 6), as well as the relative sea level history expressed in raised beaches and marine sediments.

Möller et al. $(2006,2007)$ document at least four distinct sedimentologic and geochronologic glacial/deglacial events, indicated by till sheets (till units I-IV, Fig. 6) interbedded with marine sediments (marine units I-IV, Fig. 6). Raised beach sequences were recognized at altitudes of up to $140 \mathrm{~m}$ a.s.l., indicating repeated regional glacial 


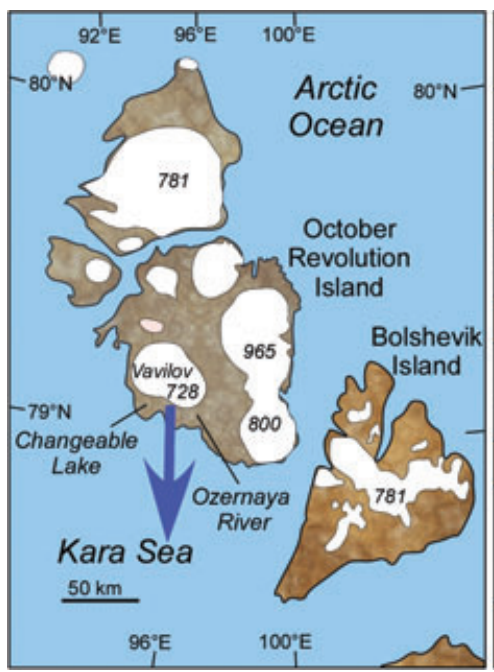

\begin{tabular}{|c|c|c|c|c|c|c|c|}
\hline Unit & $\begin{array}{l}\text { D/L Asp. } \\
\text { ratio }\end{array}$ & $\begin{array}{c}\text { ESR age } \\
(\mathrm{Ky})\end{array}$ & $\begin{array}{c}\text { GSL age } \\
(\mathrm{Ky})\end{array}$ & $\begin{array}{c}{ }^{14} \mathrm{C}_{\text {age }} \\
\text { (Ky) }\end{array}$ & $\begin{array}{c}\text { Interpreted } \\
\text { age (Ky) }\end{array}$ & $\begin{array}{c}\text { Marine } \\
\text { limit ( } m \text { a.s.l) }\end{array}$ & $\begin{array}{l}\text { Interpreted } \\
\text { MIS }\end{array}$ \\
\hline Marine IV & $\underset{(n=31)}{0.119 \pm 0.014}$ & $\begin{array}{c}20-59 \\
\text { (5 dates) }\end{array}$ & $\begin{array}{l}36->180 \\
(7 \text { dates })\end{array}$ & $\begin{array}{c}37-50 \\
\text { (15 dates) }\end{array}$ & 50 & $\begin{array}{l}>40 \\
>60\end{array}$ & $\begin{array}{c}\text { MIS } 3 \\
\text { MIS } 3 \text { (5a?) }\end{array}$ \\
\hline Till IV & & & & & & & MIS $5 d-4$ \\
\hline Marine III & $\begin{array}{c}0.196 \pm 0.015 \\
(n=42)\end{array}$ & $\begin{array}{c}77-120 \\
\text { (10 dates) }\end{array}$ & $\begin{array}{l}>59-225 \\
\text { ( } 9 \text { dates) }\end{array}$ & $\begin{array}{c}47->50 \\
\text { (4 dates) }\end{array}$ & $\begin{array}{l}>90 \\
<160\end{array}$ & 140 & MIS $6 / 5 e$ \\
\hline Till III & & & & & & & MIS 6 \\
\hline Marine II & $\begin{array}{c}0.250 \pm 0.025 \\
(n=14)\end{array}$ & $\begin{array}{c}150-231 \\
\text { (5 dates) }\end{array}$ & $>152$ & $>50$ & $>220$ & $>71$ & MIS $8 / 7 ?$ \\
\hline Till II & & & & & & & MIS 8? \\
\hline Marine I & $\begin{array}{c}0.281 \pm 0.011 \\
(n=18)\end{array}$ & $\begin{array}{l}269-492 \\
\text { (6 dates) }\end{array}$ & $\begin{array}{c}>252- \\
>473 \\
\text { (5 dates) }\end{array}$ & $>50$ & $300-400 ?$ & $>70$ & $\begin{array}{l}\text { MIS } 10 / 9 ? \\
\text { MIS } 12 / 11 ?\end{array}$ \\
\hline Till I & & & & & & & $\begin{array}{l}\text { MIS } 10 ? \\
\text { MIS } 12 ?\end{array}$ \\
\hline
\end{tabular}

Fig. 6 Stratigraphy of the Ozernaya River sites and southern October Revolution Island, Severnaya Zemlya (modified from Möller et al. 2007). The blue arrow indicates repeated ice movement directions from land towards the Kara Sea during the Late Quaternary.

loading by Kara Sea-based ice sheets. The event chronology was based on an extensive dating program including accelerator mass spectrometry (AMS) ${ }^{14} \mathrm{C}$, electron spin resonance (ESR), green-stimulated luminescence (GSL) and aspartic acid geochronology (Fig. 6). The results suggest major glaciations, followed by deglaciation and marine inundation during MIS 10-9, MIS 8-7, MIS 6-5e and MIS $5 \mathrm{~d}-3$. The most probable scenario for Severnaya Zemlya during MIS 5d-4 (Möller et al. 2006) is that there was continuous ice cover here, in contrast to the Taymyr Peninsula, which experienced an Early Weichselian deglaciation, followed by an MIS 4 readvance and subsequent deglaciation (Hjort et al. 2004). No evidence of a Late Weichselian glaciation of Severnaya Zemlya was found, neither in the form of glacial deposits nor in the form of raised beaches. This confirms other data indicating a restricted glaciation in the Kara Sea basin during MIS 2 (Svendsen et al. 2004).

Directional data including glaciotectonic deformations (Fig. 7), and clast fabric from tills and sub-till sediments, on southern October Revolution Island suggest that ice repeatedly advanced across the Ozernaya River sections from the north. These data suggest that a wet-based local ice cap on at least four occasions expanded towards the Kara Sea. However, the raised beach evidence, together with the highest altitude occurrences of the different marine units, does not fingerprint only local (Severnaya Zemlya) glaciations. A major regional ice sheet is needed to produce such high raised beaches as those observed on October Revolution Island, which represent the highest marine limit described from anywhere on the islands in the Barents Sea-Kara Sea region.

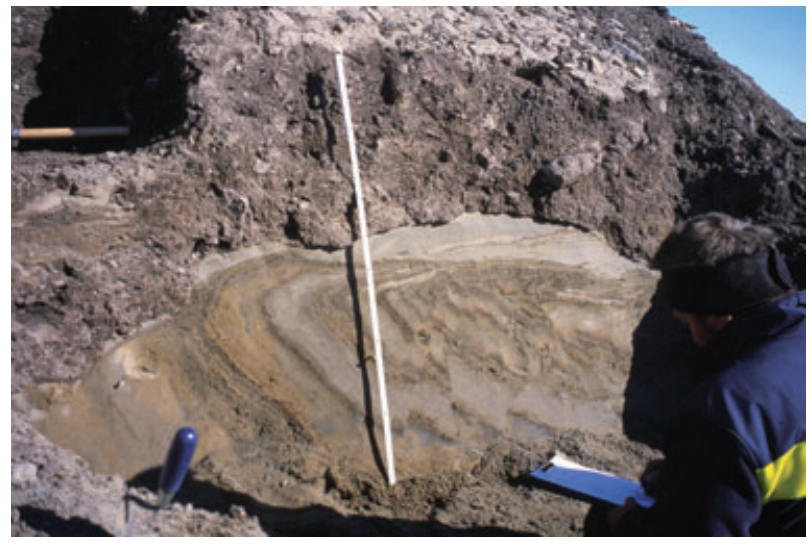

Fig. 7 Dragfold below till in the Ozernaya River sections, October Revolution Island. (Photo by Ó. Ingólfsson, 2002.)

\section{The Chelyuskin Peninsula evidence}

The Chelyuskin Peninsula, the northernmost tip of Eurasia, forms a coastal plain (0-80 m a.s.l.) towards the Kara Sea and rises to about $300 \mathrm{~m}$ a.s.l. towards the south. The Quaternary cover on Cretaceous sandstone is usually thin, but at places thicker sequences are revealed, lying as palaeo-valley/basin fills and exposed along some of the major rivers. The glacial and palaeoenvironmental history of this area (Fig. 8) is described by Möller et al. (2008). Above marine sediments of Pliocene age and fluvial braid-plain deposits of pre-Late Saalian age are two marine units, intercalated with glacial diamicts (marine units D and F, and till units C and E, Fig. 8), which are suggested to represent two full glacial cycles of 


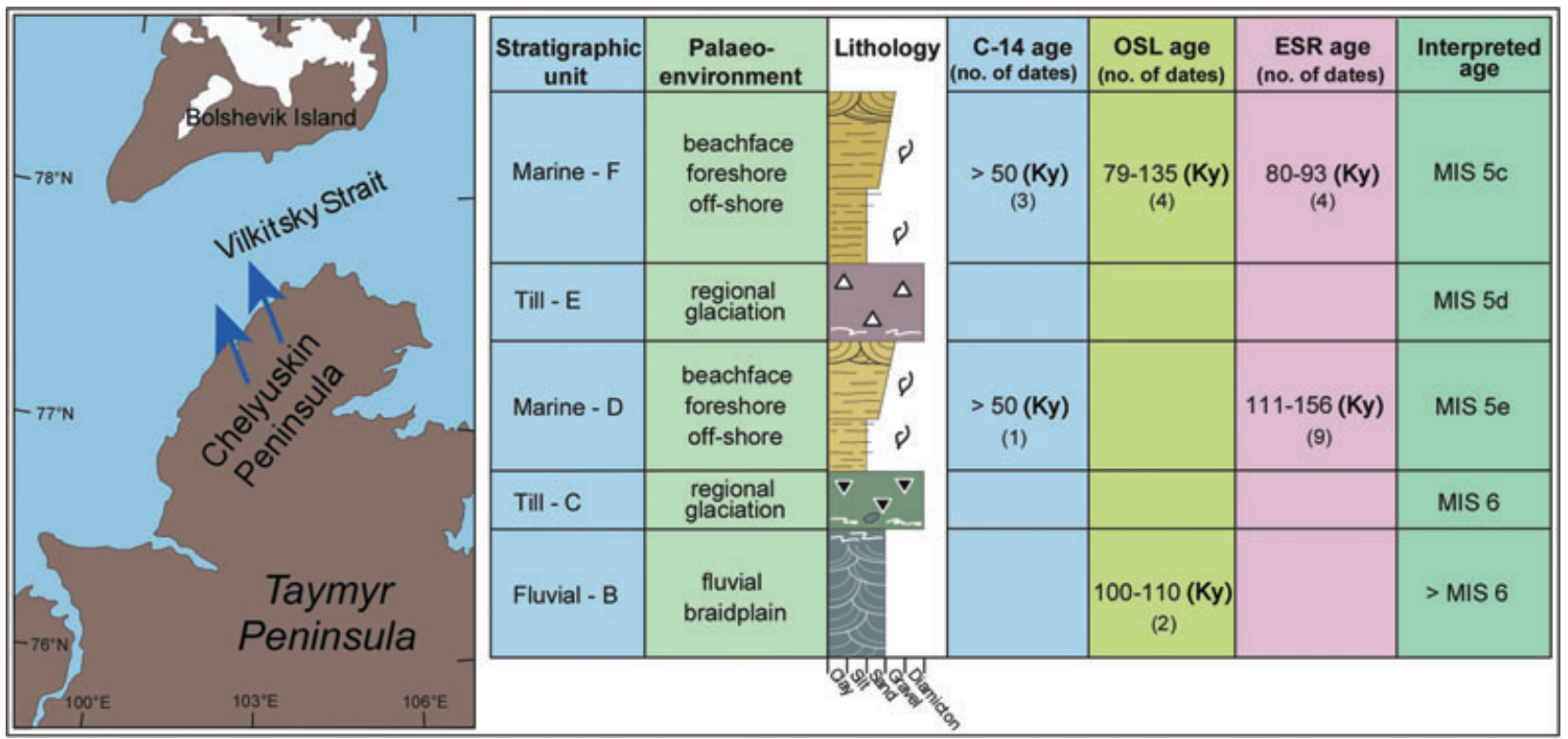

Fig. 8 Generalized Late Quaternary stratigraphy from the Chelyuskin Peninsula (modified from Möller et al. 2008). The blue arrow indicates repeated ice movement directions from land towards the Kara Sea during the Late Quaternary.

isostatic compensation, coupled to marine inundation at deglaciation. Both till units are associated with deepreaching deformation in underlying sediment, and indicate wet-based thermal conditions and a deforming bed zone. Both marine units, intercalated with the tills, show sedimentary evidence of deeper-marine environments, gradually changing to foreshore, shoreface and beachface environmental conditions as regression commences. Sediments belonging to the upper marine units (D and F) can be followed in the terrain up to an altitude of ca. $80 \mathrm{~m}$ a.s.l., and have prominent regressional shoreline scarps at 60-65 m a.s.l. Previous studies, e.g., by Šnejder (1989), have indicated that interglacial marine sediments (not dated, but most probably of Eemian/ MIS 5e age, as indicated from the mollusc fauna) reach as high as ca. $140 \mathrm{~m}$ a.s.l., which is in line with the evidence from Severnaya Zemlya (Möller et al. 2006). The event chronology is based on an extensive dating programme $\left({ }^{14} \mathrm{C}\right.$ AMS, OSL and ESR), with the ${ }^{14} \mathrm{C}$ ages suggesting an age of $>40 \mathrm{Ky}$ for both marine units. Whereas the OSL ages are considerably scattered, the ESR ages form a distinct age grouping, suggesting an MIS 5e (i.e., Eemian) age for marine unit D and an Early Weichselian age (MIS 5d/C, ca. 90 Kya) for marine unit F.

Glaciotectonic deformational structures in sediments below the unit- $\mathrm{C}$ till, the deformational structures in the lower part of the diamict and clast fabric further up (Fig. 9), imply an ice movement direction from the SSE, i.e., towards the Kara Sea shelf. This suggests that a wetbased local ice cap expanded at least once towards the
Kara Sea. However, the raised marine/beach sediments at high altitudes suggest a glacial loading more substantial than the effect from local glaciation(s).

\section{The western Taymyr Peninsula evidence}

Hjort et al. (2003) and Hjort \& Funder (2008) document two glacial events, where warm-based glaciers, originating in the mountainous inland of Taymyr, expanded northwards. At least once during the Late Quaternary did such inland-derived glaciers, after moving 50-60 km over present land areas, cross today's Kara Sea coastline. Hjort \& Funder (2008) suggest the younger of these northward-expanding glacial events is related to the Saalian glaciations (MIS 6). The last major glaciation to affect south-western Taymyr did, however, come from the Kara Sea shelf. According to OSL dates, its age was Early or Middle Weichselian (MIS 5 or MIS 4), and most probably was not younger than 70 Kya.

\section{Discussion}

Most morphological, stratigraphical and glacio-isostatic data from coastal areas around the perimeter of the Barents and Kara Seas suggest repeated Late Quaternary build-up and expansion of marine-based ice sheets (see discussions in Svendsen et al. 2004 and Forman et al. 2004). The dynamics of continental ice-sheet growth are generally poorly understood: for a long time it was held true that nucleus areas for ice-sheet growth were situated 

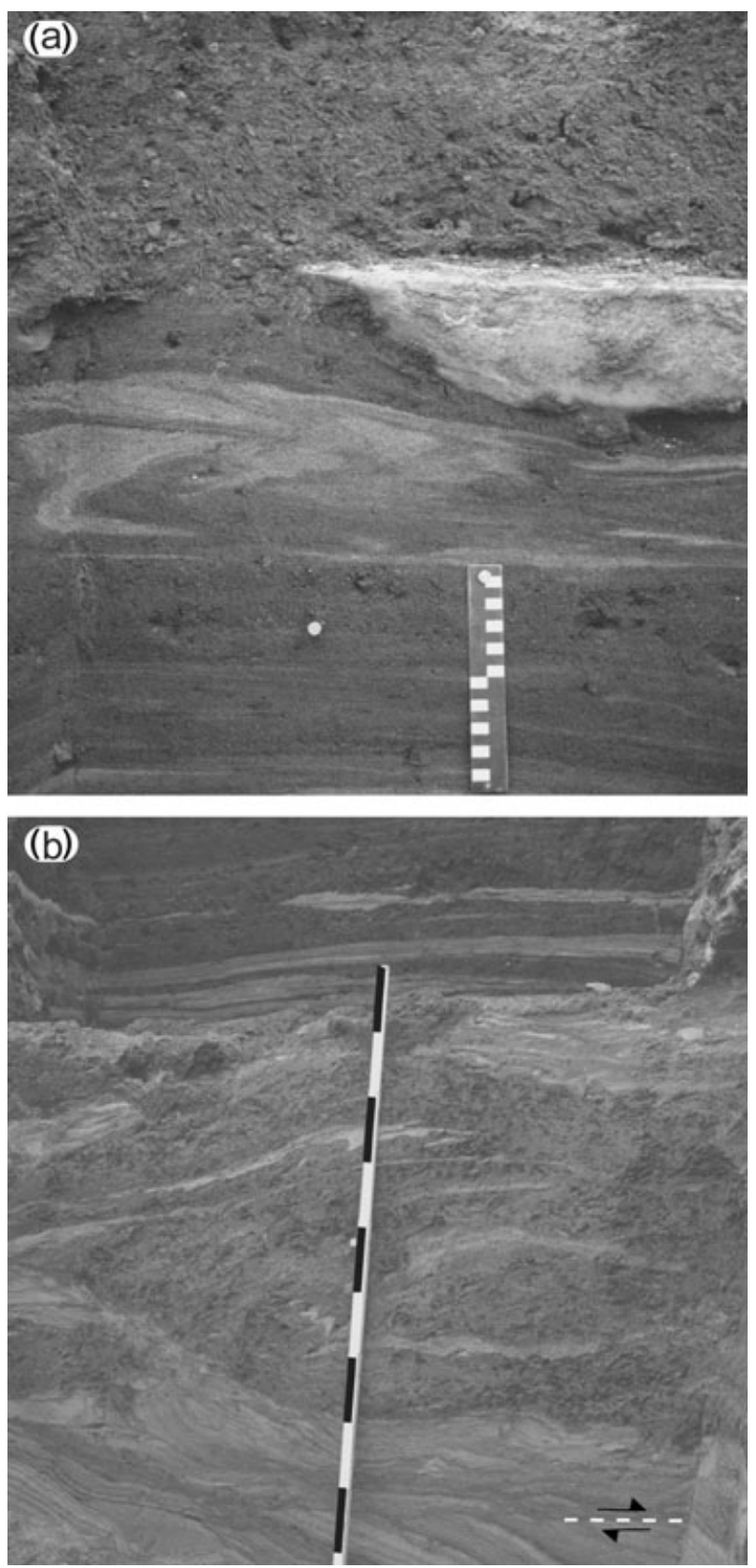

Fig. 9 Glaciotectonic structures in sections on the Chelyuskin Peninsula. (a) Marine sand incorporated in the lower par of a deforming bed diamict, showing glaciotectonic shear lamination and Z folding. (b) Contact zone between fluvial sand (Fluvial I) and diamict (Till I). The sand is folded and thrusted, and upwards is incorporated into the lower part of the diamict, here being isoclinally folded, and higher up forming subhorizontal shear lamination in the stratified diamict. (Photos by P. Möller, 1999.)

in mountainous areas, and as the glaciation altitude (the equilibrium line altitude [ELA]) was lowered with increased cooling, glaciers expanded-moisture transfer permitting-into lowland areas (Flint 1943). With the present understanding, given by high-resolution ice core and marine-sediment core data evidence, it has become evident that large-scale climate changes have on occasions in the past happened very rapidly (e.g., Johnsen et al. 1992; Grootes et al. 1993; Sachs \& Lehman 1999). It has been proposed that rapid climate cooling can lead to a sudden lowering of glaciation thresholds, causing glaciers to start growing over large lowland areas (Ives et al. 1975). We also now know that the basal thermal regime, bedrock topography and rheologic conditions of the subglacial sediments and bedrock are critical for ice-sheet expansion and retreat, and that marine-based ice sheets are instable and prone to massive ice-discharge events (Heinrich 1988; Broecker \& Denton 1989; Siegert \& Dowdeswell 1996; Kjær et al. 2006). Geological data suggest that the LGM Barents Sea ice-sheet built up, reached its maximum extent, and subsequently retreated and disintegrated in about $10 \mathrm{Ky}$, between 22 and $12 \mathrm{Kya}$ (Landvik et al. 1998). But how do marine-based ice sheets grow?

This puzzle was addressed by Hughes (1987), where he developed ideas previously published by, e.g., Mercer (1970), Hughes et al. (1977) and Grosswald (1980). He proposed that a marine-based ice sheet could form when permanent sea ice thickened into an ice shelf, and subsequently, as the ice shelf thickened, it could eventually become a grounded ice sheet. Siegert et al. (2002) developed these ideas further when they modelled the LGM build-up of a marine-based Barents Sea ice sheet. They suggested that ice might initially have accumulated on the archipelagos located across the northern edge of the Eurasian continental shelf (Fig. 1) and in northern Scandinavia. The weight of the ice caused crustal depression, resulting in an upward bulging of the shallow central regions of the Barents Sea. The resultant uplift, combined with the lowering of global sea levels caused by continental ice-sheet build-up, may have allowed ice to flow in from ice caps on the Arctic islands and the adjacent Scandinavian ice sheet, or it may have formed in situ from thickening sea ice, as proposed by Hughes (1987). Möller et al. (2007) suggested a similar model for the repeated build-up of ice sheets in the Kara Sea area, based on field evidence from coastal October Revolution Island, Severnaya Zemlya.

The simplest explanation for the structural, lithostratigraphical and relative sea level data from Marresale (the Yamal Peninsula), Cape Shpindler (the Yugorski Peninsula), Ozernaya River (October Revolution Island in Severnaya Zemlya) and the Chelyuskin Peninsula is that land areas in the perimeter of the Kara Sea repeatedly acted as ice-sheet nucleation centres, with ice flowing from land to sea (Fig. 10). We propose a simple model, based on the ideas of Hughes (1987) and Siegert et al. (2002) for stepwise ice-sheet build-up in the Kara Sea. 
Fig. 10 Overview of palaeo-ice directions from the perimeter of the Kara Sea.



1 At the onset of glaciations, ice caps start to grow on mountainous areas surrounding the Kara Sea (the Pai Hoi and northernmost Polar Urals, and the Byrranga Mountains on the Taymyr Peninsula). Existing ice caps and glaciers in the Severnaya Zemlya and Novaya Zemlya archipelagos expand.

2 As global sea levels fall and isostatic load around the perimeter of the Kara Sea increases, water depths decrease over large areas on the shallow Kara Sea shelf. This facilitates the formation of a stable thick sea-ice cover and later ice-shelf formation. Ice flows into the Kara Sea basin from the surrounding highlands (Fig. 10). The field evidence suggests that the expanding ice was predominantly warm-based, as it deposited tills and caused ductile deformation of underlying sediments.

3 A Kara Sea ice-sheet dome forms as a result of a combination of ice flowing into the Kara Sea basin and snow accumulation on the grounded ice shelf. Possibly the build-up of a Kara Sea ice sheet during each glaciation event led to the build-up of a Barents Sea ice sheet; if so, Kara Sea ice sheets developed before the passage of moist air from the west across the Barents Sea was blocked.
4 As the ice sheet thickens, ice flow is reversed and the ice sheet starts to infringe on the surrounding land areas. The field evidence suggests that at this stage the ice sheet was cold-based towards its margins and over inception areas, and it did not deposit tills or cause significant glaciotectonic deformations in these areas any more.

The marine-based ice sheet was probably unstable and sensitive to sea level changes. As global sea levels rose, when continental ice sheets disintegrated and melted during deglaciation events (terminations), the Kara Sea ice sheet rapidly lost mass through calving. This resulted in marine inundation and deposition of marine strata in the geological record in areas surrounding the Kara Sea. High raised beaches (e.g., up to $140 \mathrm{~m}$ a.s.l. in Severnaya Zemlya) formed as a consequence of rapid deglaciation and heavy crustal depression by the ice sheet.

There are a number of aspects to this simple model that might be addressed and tested.

- Is it possible to simulate scenarios that fit the field observations on the directions of ice movement during ice-sheet build-up, and reversing the ice flow as the ice dome grows, using state-of-the-art glaciological models? 
- How do we produce warm-based glaciers at the onset of glaciations in High-Arctic settings like Severnaya Zemlya, where present-day glaciers are predominantly cold-based? Is it possibly a consequence of an increase in flow rate as ice entered the Kara Sea sedimentary basin?

- Why did an ice sheet not form over the Kara Sea basin during the last (MIS 2) glaciation? Does the answer lie in a very strong palaeoclimatic gradient across the Barents Sea-Kara Sea region, and because this area was in a precipitation shadow during the Scandinavian ice-sheet LGM?

\section{References}

Astakhov V.I., Kaplyanskaya F.A. \& Tarnogradsky V.D. 1996. Pleistocene permafrost of west Siberia as a deformable glacier bed. Permafrost and Periglacial Processes 7, 165-191.

Broecker W.S. \& Denton G.H. 1989. The role of ocean-atmosphere reorganizations in glacial cycles. Geochimica Cosmochimica Acta 53, 2465-2501.

Flint R.F. 1943. Growth of North American ice sheet during the Wisconsin age. Geological Society of America Bulletin 54, 325-362.

Forman S.L., Ingólfsson Ó., Gataullin V., Manley W.F. \& Lokrantz H. 2002. Late Quaternary stratigraphy, glacial limits, and palaeoenvironment of the Marresale area, western Yamal Peninsula, Russia. Quaternary Research 57, 355-370.

Forman S.L., Ingólfsson Ó., Manley W.F. \& Lokrantz H. 1999. Late Quaternary stratigraphy of W. Yamal Peninsula, Russia: new constraints on the configuration of the Eurasian ice-sheet. Geology 27, 807-810.

Forman S., Lubinski D., Ingólfsson Ó., Zeeberg D., Snyder J.A. \& Matishov G.G. 2004. A review of postglacial emergence on Svalbard, Franz Josef Land and Novaya Zemlya, northern Eurasia. Quaternary Science Reviews 22, 1391-1434.

Gataullin V. 1988. Verhnečetvertičnye otloženija zapadnogo poberežja poluostrova Jamal. (Upper Quaternary deposits of the western coast of the Yamal Peninsula.) PhD thesis, All-Russian Geological Institute, Leningrad.

Grootes P.M., Stuiver M., White J.W.C., Johnsen S. \& Jouzel J. 1993. Comparison of oxygen isotope records from the GISP2 and GRIP Greenland ice cores. Nature 366, 552-554.

Grosswald M.G. 1980. Late Weichselian ice sheets of northern Eurasia. Quaternary Research 13, 1-32.

Grosswald M.G. \& Hughes T.J. 2002. The Russian component of an Arctic ice sheet during the Last Glacial Maximum. Quaternary Science Reviews 21, 121-146.

Heinrich H. 1988. Origin and consequence of cyclic ice rafting in the northeast Atlantic Ocean during the past 130,000 years. Quaternary Research 29, 142-152.

Hjort C., Fedorov G., Funder S. \& Onishev A. 2003. Taymyr Quaternary geology 2002-the glaciers did not always come from the Kara Sea. Polarforskningssekretariatets Arsbok 2002, 80-84.
Hjort C. \& Funder S.F. 2008. Mountain-derived versus shelf-based glaciations on the western Taymyr Peninsula, Siberia. Polar Research 27, 273-279 (this issue).

Hjort C., Möller P. \& Alexanderson H. 2004. Weichselian glaciation of the Taymyr Peninsula, Siberia. In J. Ehlers \& P.L. Gibbard (eds.). Quaternary glaciations-extent and chronology. Part 1. Europe. Pp. 359-367. Amsterdam: Elsevier.

Hughes T.J. 1987. The marine ice transgression hypothesis. Geografiska Annaler 69, 237-250.

Hughes T.J., Denton G.H. \& Grosswald M.G. 1977. Was there a late Würm ice sheet? Nature 266, 596-602.

Ives J.D., Andrews J.T. \& Barry R.G. 1975. Growth and decay of the Laurentide Ice Sheet and comparisons with Fenno-Scandinavia. Die Naturwissenschaften 62, 118-125.

Johnsen S.J., Clausen H.B., Dansgaard W., Fuhrer K., Gundestrup N., Hammer C.U., Iversen P., Jouzel J., Stauffer B. \& Steffensen J.P. 1992. Irregular glacial interstadials recorded in a new Greenland ice core. Nature $359,311-313$.

Kjær K. H., Larsen E., Funder S., Demidov I. N., Jensen M., Håkansson L. \& Murray A. 2006. Eurasian ice-sheet interaction in northwestern Russia throughout the late Quaternary. Boreas 35, 444-475.

Lambeck K., Purcell A., Funder S., Kjær K.H., Larsen E. \& Möller P. 2006. Constraints on the Late Saalian to early Middle Weichselian ice sheet of Eurasia from field data and rebound modelling. Boreas 35, 539-575.

Landvik J.Y., Bondevik S., Elverhøi A., Fjeldskaar W., Mangerud J., Salvigsen O., Siegert M.J., Svendsen J.I. \& Vorren T.O. 1998. The Last Glacial Maximum of the Barents Sea and Svalbard area: ice sheet extent and configuration. Quaternary Science Reviews 17, 43-75.

Larsen E., Kjaer K.H., Demidov I.N., Funder S., Grosfjeld K., Houmark-Nielsen M., Jensen M., Linge H. \& Lyså A. 2006. Late Pleistocene glacial and lake history of northwestern Russia. Boreas 35, 394-424.

Lokrantz H., Ingólfsson Ó. \& Forman S.L. 2003. Glaciotectonised Quaternary sediments at cape Shpindler, Yugorski Peninsula, Arctic Russia: implications for glacial history, ice-movements and Kara Sea Ice Sheet configuration. Journal of Quaternary Research 18, 527-543.

Lowe J.J. \& Walker M.J.C. 1998. Reconstructing Quaternary environments. Harlow: Longman.

Mercer J.H. 1970. A former ice sheet in the Arctic Ocean? Palaeogeography, Palaeoclimatology, Palaeoecology 8, 19-27.

Möller P., Federov G., Pavlov M., Seidenkrantz M.-S. \& Sparrenbom C. 2008. Glacial and palaeoenvironmental history of the Cape Chelyuskin area, Arctic Russia. Polar Research 27, 222-248 (this issue).

Möller P., Lubinski D., Ingólfsson Ó., Forman S.L., Siedenkrantz M.-S., Bolshiyanov D.Y., Lokrantz H., Antonov O., Pavlov M., Ljung K., Zeeberg J.J. \& Andreev A. 2006. Severnaya Zemlya, Arctic Russia: a nucleation area for Kara Sea ice sheets during the Middle to Late Quaternary. Quaternary Science Reviews 25, 2894-2936. 
Möller P., Lubinski D., Ingólfsson Ó., Forman S.L., Siedenkrantz M.-S., Bolshiyanov D.Y., Lokrantz H., Antonov O., Pavlov M., Ljung K., Zeeberg J.J. \& Andreev A. 2007. Erratum to: Severnaya Zemlya, Arctic Russia: a nucleation area for Kara Sea ice sheets during the Middle to Late Quaternary (2006, Quaternary Science Reviews 25, 2894-2936.) Quaternary Science Reviews 26, 1149-1191.

Raab A., Melles M., Berger G.W., Hagedorn B. \& Hubberten H.-W. 2003. Non-glacial paleoenvironments and the extent of Weichselian ice sheets on Severnaya Zemlya, Russian High Arctic. Quaternary Science Reviews 22, 2267-2283.

Sachs J.P. \& Lehman S.J. 1999. Subtropical North Atlantic temperatures 60,000 to 30,000 years ago. Science 286, 756-759.

Siegert M.J. \& Dowdeswell J.A. 1996. Topographic control on the dynamics of the Svalbard-Barents Sea Ice Sheet. Global and Planetary Change 12, 27-39.

Siegert M.J., Dowdeswell J.A., Hald M. \& Svendsen J.I. 2001. Modelling the Eurasian Ice Sheet through a full (Weichselian) glacial cycle. Global and Planetary Change 31, 367-385.
Siegert M.J., Dowdeswell J.A., Svendsen J.I. \& Elverhøi A. 2002. The Eurasian Arctic during the last ice age. American Scientist 90, 32-39.

Šnejder [Schneider] G.V. 1989. Stratigrafija kajnozojskih otloženij i nekotore čerty rel'efa severovostočnoj okonečnosti Tajmyrskogo Poluostrova. (Stratigraphy of Cenozoic deposits of some topographic features of the Taymyr Peninsula, north-eastern extremity.) $P G O$ Sevmorgeologija 1989, 35-48.

Svendsen J.I., Alexandersson H., Astakhov V., Demidov J., Dowdeswell J.A., Henriksen M., Hjort C.,

Houmark-Nielsen M., Hubberten H., Ingólfsson Ó., Jakobsson M., Kjær K., Larsen E., Lokrantz H., Luunka E.P., Lysa A., Mangerud J., Maslenikova O., Matioushkov A., Murray A., Möller P., Niessen F., Saarnisto M., Siegert M., Stein R. \& Spielhagen R. 2004. Ice sheet history of northern Eurasia. Quaternary Science Reviews 22, 12291271.

Velichko A.A., Kononov Y.M. \& Faustova M.A. 1997. The last glaciation on Earth: size and volume of ice-sheets. Quaternary International 41/42, 43-51. 